\title{
Impact of Human Activities on Soil Contamination
}

\author{
Fernando José Garbuio, ${ }^{1}$ Jeffrey L. Howard, ${ }^{2}$ and Larissa Macedo dos Santos ${ }^{3}$ \\ ${ }^{1}$ Departamento de Ciência do Solo, Instituto Federal Catarinense, Santa Rosa do Sul, SC 48202, Brazil \\ ${ }^{2}$ Department of Geology, Wayne State University, Detroit, MI, USA \\ ${ }^{3}$ Department of Chemistry, Federal Technological University of Paraná, Pato Branco, PR, Brazil \\ Correspondence should be addressed to Fernando José Garbuio, fgarbuio@yahoo.com.br
}

Received 17 December 2012; Accepted 17 December 2012

Copyright (C) 2012 Fernando José Garbuio et al. This is an open access article distributed under the Creative Commons Attribution License, which permits unrestricted use, distribution, and reproduction in any medium, provided the original work is properly cited.

The impacts of human activities on soil contamination are many and varied. The extent of human impact is now so pervasive and profound that there is currently much discussion about the "Anthropocene", a new geologic era characterized by anthropogenic disturbances of the geologic record. Many of the problems recognized during the 1970s linger on, including the effects of acid rain and airborne deposition of soot, fly ash, and other potentially toxic particulates. Further, the scope of the problem has grown significantly with economic growth in previously less developed nations such as China and India. The effects of human activities vary with land use, ranging from agricultural wastes such as farm animal sewerage and fertilizer runoff, to commercial and industrial wastes of every conceivable type and magnitude. Over the years, the list of toxic contaminates has also grown, so that it not only includes heavy metals, radionuclides, and organic compounds of anthropogenic origin, but pharmaceuticals, explosives, and previously unknown biological pathogens. The field of soil remediation has also grown tremendously over the past few decades. The goal of this special issue is to further explore the effects of human activities on soil contamination. Topics to be examined include the nature and extent of soil contamination, state of the art methodologies for studying soil and related groundwater contamination, and innovative techniques for remediation.

This special issue initially contains five articles, with plans for future publication of additional papers. The papers deal with heavy metals and toxic organics, as well as soil acidification and the effects of military explosives on soil. In the paper "Occurrence of vanadium in Belgian and European alluvial soils," V. Cappuyns and E. Slabbinck bring attention to the possible effects of $\mathrm{V}$ as a soil contaminant. They document the nature and extent of $\mathrm{V}$ contamination in alluvial soils developed in three industrialized drainage basins in Belgium, and from other areas in Europe. Their results suggest that the mobility of $\mathrm{V}$ is low, but nevertheless worthy of further investigation. B. V. Kjellerup et al. examine the effects of biodecomposition by bacteria as a remedial tool for PCB contamination in the paper entitled "Spatial distribution of $P C B$ dechlorinating bacteria and activities in contaminated soil." Their results support the use of the method for remediating sediments, whereas use in contaminated soils faces further challenges. In the paper called "Acidification and nitrogen eutrophication of Austrian forest soils" R. Jandl et al. reevaluate the effects of acidic deposition and nitrogen on forests soils. Interestingly, $\mathrm{pH}$ has risen in the soils studied as a result of air pollution mitigation and nitrate leaching into the groundwater is not found to be a large-scale problem. The high levels of nitrogen deposition have actually led to an unexpected increase in the forest productivity. J. Pichtel reviews the effects of military explosive wastes on soils in the article entitled "Distribution and fate of military explosives and propellants in soil: a review." He shows that soils worldwide are contaminated by the chemically active components of explosives and propellants. These compounds undergo varying degrees of chemical and biochemical transformation and appear to be common groundwater contaminants. Thus, there appears to be an urgent need to identify and remove such hazards from contaminated soils. In the paper " $A$ critical evaluation of single extractions from the SMT program to determine trace element mobility in sediments," V. Cappuyns compares two commonly applied single extraction procedures, ammonium-EDTA and acetic acid, for evaluating heavy metal contamination in 
soils. The results underscore the difficulties of relating single extractions to phytoavailability, and thus the need for further work.

Fernando José Garbuio

Jeffrey L. Howard

Larissa Macedo dos Santos 

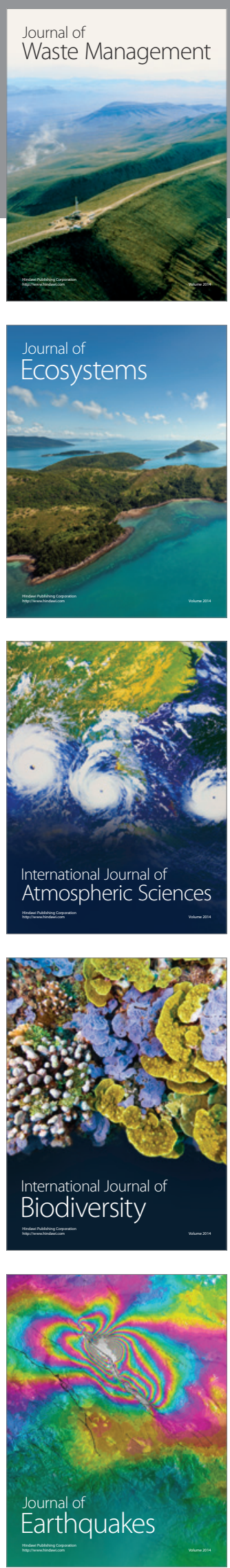
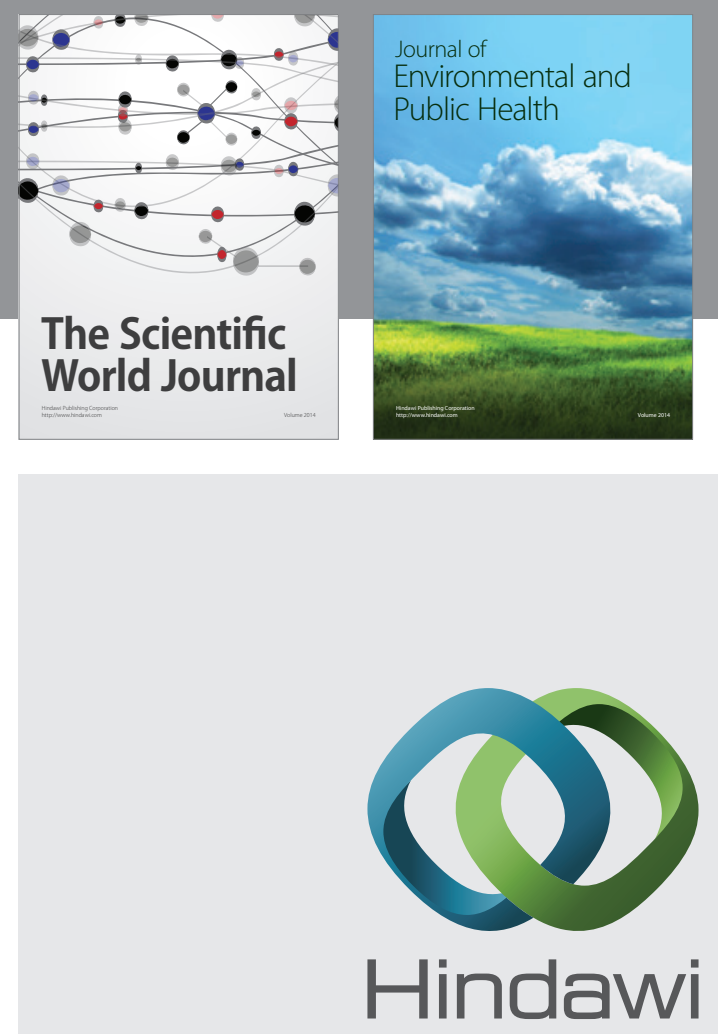

Submit your manuscripts at

http://www.hindawi.com
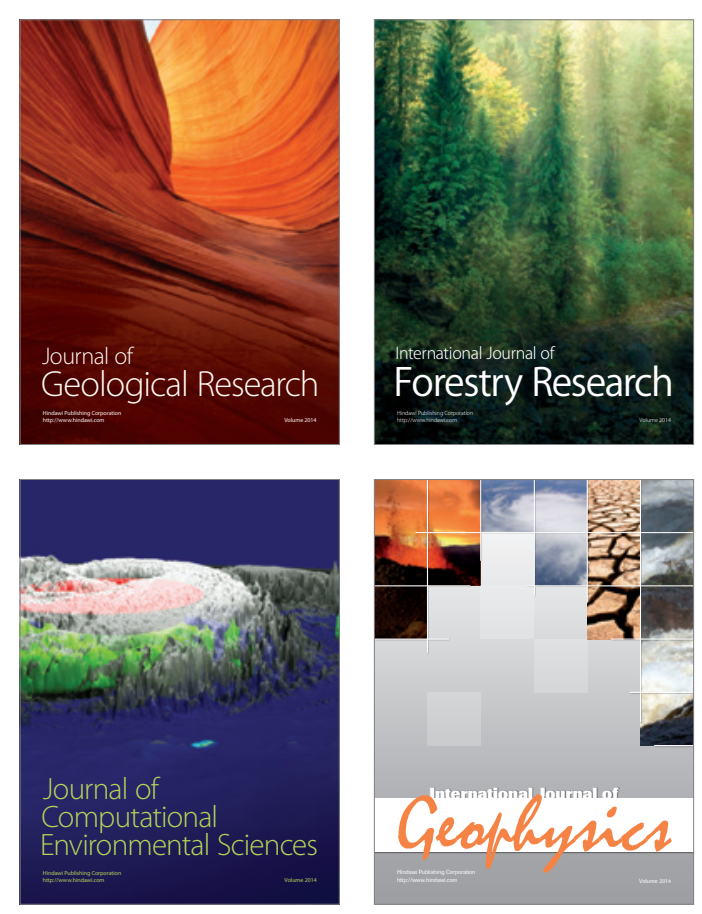
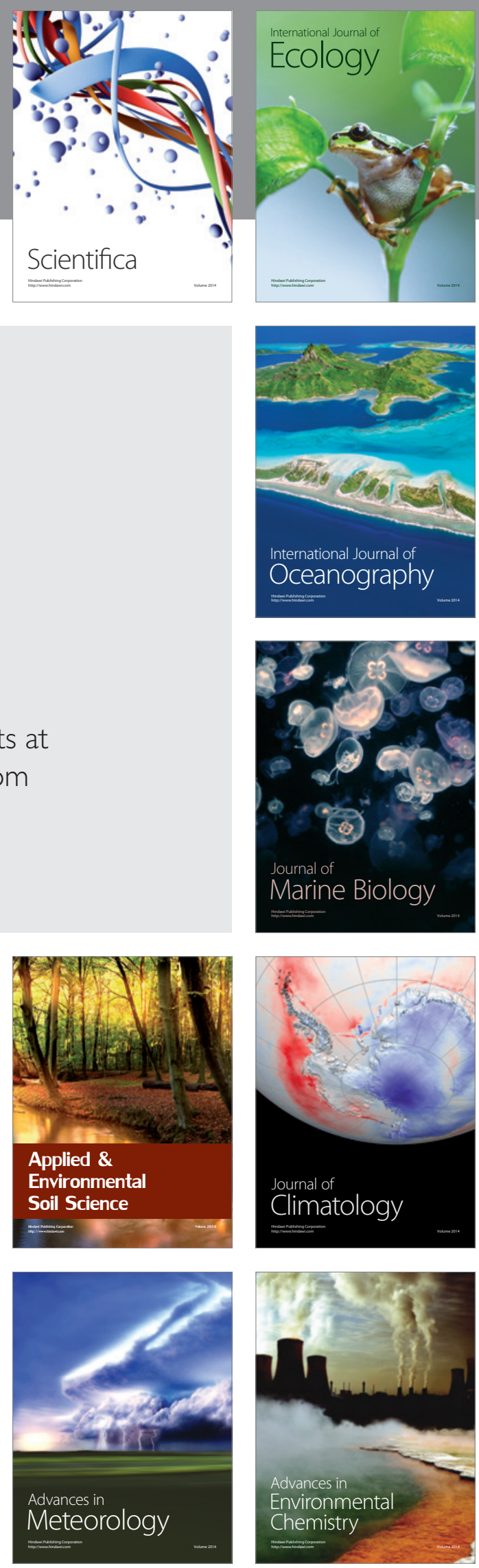